\title{
THE EFFECT OF ENVIRONMENTAL PERFORMANCE INVESTMENTS ON FINANCIAL PERFORMANCE: ANALYSIS OF CROATIAN COMPANIES
}

\author{
Galant, A., Cvek, D.
}

Adriana Galant / Juraj Dobrila University of Pula, Faculty of economics and tourism "Dr. Mijo Mirković", Zagrebačka 30, 52100 Pula, Croatia. Email: adriana.galant@unipu.hr.

Dajana Cvek / High School of Applied Art and design, Radićeva 19, 52100, Pula, Croatia. Email: dajana.cvek@gmail.com.

\begin{abstract}
More attention is being paid to companies' environmental performance these days. It includes the consideration of how a company's business operations affect the natural environment in which it operates. In order to improve its environmental performance, various investments are essential. However, one important question is how such environmental performance investments affect the company's financial performance. The theoretical background indicates that both positive and negative effects on financial performance are possible; however, previous results show that environmental performance has a predominantly positive effect on financial performance. Considering the importance of environmental performance, the aim of this research is to determine if there is a positive relationship between environmental performance investments and financial performance. Investments in new longterm assets are used as a proxy for environmental performance investments since newer long-term assets are considered to be more environmentally acceptable than the older ones, while financial performance is measured with the business result (net profit or loss). The data was analysed by using multivariate regression analysis. The sample included 150 Croatian large-sized companies. The results reveal that there is a positive relationship between environmental performance investments and financial performance. Therefore, such investments are of interest to both the environment and the company since they help to preserve the natural environment and, at the same time, improve the company's financial performance.

Implications for Central European audience: The effect of environmental performance investments on financial performance has been tested on a sample comprising companies from Central European country, Croatia. Obtained results can be of interests also for audience from other Central European countries with similar characteristics as Croatia due to common historical features (transitional experience).
\end{abstract}

Keywords: environmental performance investments; financial performance; environmental accounting; Croatia

JEL Classification: M41, Q56, L25 


\section{Introduction}

One of the main aims of for-profit companies is profit maximisation, i.e. the maximisation of the shareholders' value. However, contemporary business conditions require taking into consideration the interests of a larger number of stakeholders when running a business. Nowadays, stakeholders are not only interested in the economic performance of a company but also in the environmental and social performance that fall under the corporate social responsibility (CSR) of a company. Environmental performance includes taking care of the natural environment in which the company operates so that it can be preserved as much as possible for future generations. If a company wants to have an adequate level of environmental performance, it is essential to invest in it.

Environmental performance investments, as well as other investments undertaken by a company, can affect its financial performance. Therefore, an important and interesting question related to environmental investments is whether such investments pay off for the company (i.e. increase profitability) or whether they reduce the company's profitability. Carroll (1991) proposed that economic responsibility (i.e. being profitable) should be the core responsibility of a company. Therefore, it is reasonable to assume that good financial performance should also be related to higher environmental performance investments.

In line with conventional wisdom, environmental performance investments result in additional costs for the company, leading to a negative effect on its financial performance (i.e. reduced profitability) (Nehrt, 1996). However, more recent evidence (Al-Tuwaijri et al., 2004; Nakao et al., 2007; Drejeris \& Oželienè, 2019) suggests that improved environmental performance (a result of environment performance investments) could also result in financial benefits for the company (i.e. increased profitability) in the form of avoiding penalties, decreasing costs due to energy savings, increasing sales due to customers' preference to buy products/services from an environmentally friendly company, etc.

Considering the mentioned opposing scenarios, the main purpose of this research is to explore the effect of environmental performance investments on the company's financial performance. Based on theoretical reasoning and previous results, it is expected that the positive effects of environmental performance investments on financial performance will outperform the negative ones. Therefore, financial performance should be improved as a consequence of environmental performance investments.

The main contribution of this research is in detecting whether environmental performance investments contribute to the company's financial performance. The research will be conducted on a sample comprising companies from Croatia, which will allow us to reach a conclusion regarding a small transition country (Croatia) in the short term.

The remainder of the paper is organised as follows. Based on the theoretical background and literature review, the main hypothesis of this research is developed. The following section includes research methodology, after which the results of testing the hypothesis are presented. The paper ends with a conclusion and a discussion section. 


\section{Theoretical background and literature review}

\subsection{Corporate social responsibility (CSR)}

The concept of corporate social responsibility (CSR) has become more and more popular in recent years, and a large number of companies are implementing it into their daily business operations. CSR can be defined in different ways. In line with this, Dahlsrud (2008) identified 37 different definitions of CSR present in literature. His research resulted in the identification of five main dimensions of the CSR concept: economic, stakeholder, social, voluntariness and environmental (Dahlsrud, 2008). As noted before, there are a lot of different definitions of CSR; however, one definition, provided by the European Commission, includes all the previously mentioned dimensions: "a concept whereby companies integrate social and environmental concerns in their business operations and in their interaction with their stakeholders on a voluntary basis" (European Communities, 2002).

According to Carroll (1991), the first ethical aim of a company should be profitability and fulfilling this aim represents the precondition for achieving other dimensions of social responsibility. Due to its importance, the economic dimension of CSR is placed at the bottom of the pyramid of corporate social responsibility (Carroll, 1991). In line with this, if a company wants to be socially responsible, it needs to be profitable first. The stakeholder dimension of the CSR concept can be explained with the stakeholder theory, which was first introduced by Freeman in 1984. The stakeholder theory "takes into account the individuals or groups with a 'stake' in or claim on the company" (Melé, 2008). In line with this theory, stakeholders can be defined as "groups or individuals who benefit or are harmed by corporate actions" (Melé, 2008). Therefore, the managers running a company should consider the effects of their actions on wider groups of individuals or groups (i.e. stakeholders), and not just on shareholders. The social dimension of CSR calls for taking care of the society within which the company operates. Another dimension of CSR is voluntariness, which refers to taking actions that are above legal obligations. If some actions or behaviours are prescribed by the law, they cannot represent a socially responsible action.

The last CSR dimension is environmental, which is the one that this paper focuses on. Environmental performance represents a critical component of corporate social performance (Stanwick \& Stanwick, 1998). It refers to taking care of the natural environment within which the company operates. The importance of the environmental components of the CSR concept was also emphasised by Elkington (1994), who presented the triple bottom line concept (3P: people, planet and profit). In line with the 3P concept, companies need to integrate economic, social and environmental performance in order to achieve social responsibility and sustainability.

Different benefits of CSR are identified in the literature. Perić and Turalija (2018) identified the following: retaining regular buyers and clients, but also acquiring new ones, who are sensitive to CSR issues, improved corporate image and competitiveness, better relationships with stakeholders and improved financial performance. 


\subsection{Environmental performance investments}

Nowadays, environmental issues are of concern for society, and because of this, companies, especially the ones in polluting industries, face "tight governmental regulations, increased media attention, and strong environmental activism" (Berrone \& Gomez-Mejia, 2009, p. 103).

In order to manage such environmental issues, companies should introduce some kind of environmental management. Environmental management includes "all efforts to minimise the negative environmental impact of the company's products throughout their life cycle" (Klassen \& McLaughlin, 1996, p. 1199). The environmental impacts of the company's processes and products and the environmental regulations and initiatives undertaken by environmental management also need to be considered while defining and achieving a business strategy (Klassen \& McLaughlin, 1996). The importance of environmental management can be identified from the resource dependence theory, according to which companies are "dependent upon various aspects of their environments to supply critical resources" (Kassinis \& Vafeas, 2006, p. 145).

According to Russo and Fouts (1997), the company's level of investments in environmental performance depends on whether the company aims to just comply with the law or it goes beyond just compliance by trying to embrace pollution prevention. In the first situation, environmental investments affect only physical assets since compliance "is achieved by the addition of pollution-removing or filtering devices to the existing assets". The second situation (going beyond just compliance) implies that companies develop expertise or skills for managing new environmental technologies and processes (Russo \& Fouts, 1997, p. 538).

\subsection{Environmental performance and financial performance}

How a company manages its environmental performance can have an important role in its financial performance (Klassen \& McLaughlin, 1996). There is a significant amount of previous studies dealing with the relationship between environmental performance and financial performance. Al-Tuwaijri et al. (2004) stated that the relationship between environmental performance and financial performance was based on contradictory theoretical support, which could not be clarified by empirical research. Due to that, the results of previous studies were conflicting (Konar \& Cohen, 2001; Al-Tuwaijri et al., 2004), ranging from negative to positive, but they also detected no relationship between the two performances.

In line with Russo and Fouts (1997, p. 540), environmental performance can enhance profits through two intangible factors: reputation and political acumen ("the ability to influence public policies in ways that confer a competitive advantage"). Having a reputation as a leader in environmental performance could increase sales revenues collected from customers that are sensitive to environmental issues. The companies focused on compliance policy (employment of legislation and political lobbying) can develop political acumen to defend themselves from environment protection demands coming from a society that result in avoiding additional costs related to environmental performance and improving their competitive advantage (Russo \& Fouts, 1997).

Klassen and McLaughlin (1996) suggest that the company's financial performance can be affected by environmental performance through increased revenues and decreased costs. They also indicate that increased sales are related to customers' preferences to buy from 
environmentally-oriented companies. As for the decreased costs, they can be the result of avoiding "future environmental spills, crises and liabilities" and minimising material waste and inefficient processes (Klassen \& Mc Laughlin, 1996, p. 1201).

By implementing the strategies for improving and promoting environmental performance and by reducing the negative environmental impact, companies gain environmental legitimacy (Berrone \& Gomez-Mejia, 2009). Such environmental legitimacy can result in different benefits for the company. Berrone and Gomez-Mejia (2009) summarised the following benefits: better access to resources, an easier way of attracting and arranging better conditions with employees, customers and other business partners, a reduced risk of loss related to innovations, reduced risk of legal sanctions, penalties, high insurance premiums and remediation costs related to an environmental mishap, a reduced risk from stakeholder scrutiny and social sanctions, and finally, a reduction in idiosyncratic company risk. Considering these benefits, increasing revenues or decreasing costs can be the result of improved environmental performance.

An early study by Russo and Fouts (1997) found that high levels of environmental performance were positively associated with enhanced profitability measured with return on asset (ROA). Similarly, Klassen and McLaughlin (1996) discovered that positive stock returns were found for companies that received an environmental performance reward, and at the same time, negative stock returns were measured for companies dealing with an environmental crisis. Similarly, Al-Tuwaijri et al. (2004) found that "good" environmental performance was positively associated with "good" economic performance (industry adjusted annual return).

Pekanov Starčević et al. (2017) explored whether going green in Croatia paid off and noted that the companies selling green products and services had a higher turnover. The results of the study conducted by Konar and Cohen (2001) show that for a manufacturing company, a $10 \%$ reduction in the emissions of toxic chemicals results in an increase in the market value of \$34 million. On a sample of Japanese companies, Nakao et al. (2007) found that environmental performance had a positive effect on financial performance and vice versa, but also that this tendency to test a two-way relationship was a recent phenomenon.

Another way in which environmental performance can lead to better financial performance is through employees' involvement. Based on research conducted in the oil industry (a highly polluting sector), De Roeck and Delobbe (2012) argue that environmental CSR initiatives can help a company to have a strong relationship with employees and gain their support.

However, not all previous results indicate a positive relationship. Research by Link and Naveh (2006) showed that the improvement of environmental performance (results from ISO 14001 implementation) did not lead to improved business performance, but that it also did not harm it.

Horváthová (2010) conducted a meta-analysis of 64 studies dealing with the relationship between environmental and financial performance and discovered that the positive outcome dominates. The positive outcome was reported in 35 studies, the negative one in 10 studies, while the remaining studies (19) showed insignificant results (Horváthová, 2010). Another meta-analysis conducted by Endrikat et al. (2014) integrated the results of 149 studies and revealed that there was a positive and a partially bidirectional relationship between environmental and financial performance. 
Based on the previous research, it is evident that better environmental performance has positive effects on financial performance. To achieve better environmental performance, investments in environmental performance (environmental performance investments) are essential. Therefore, environmental performance investments should increase the financial performance of a company by improving its environmental performance. By taking into account the previously mentioned benefits of improved environmental performance and the previous empirical results, the following hypothesis is defined:

H1: Environmental performance investments have a positive effect on financial performance in the short term.

In addition to testing the relationship between environmental investments performance and financial performance, the effects of company size and leverage were considered. It is expected that larger companies will have higher values of financial performance. As for the leverage ratio, it is expected that it will have a negative effect on financial performance.

Based on the above mentioned, research model can be written as the following equation:

$$
\mathrm{FP}=\alpha+\beta_{1 \mathrm{EPI}}+\beta_{2 \text { SIZE }}-\beta_{3 \mathrm{LEV}}+\varepsilon
$$

Where:

$\mathrm{FP}=$ financial performance

$\mathrm{EPI}=$ environmental performance investments

SIZE = company size

$\mathrm{LEV}=$ leverage

\section{Research methodology}

\subsection{Variables}

\section{Environmental performance investments}

Different ways of measuring environmental performance can be found in literature, including the aggregate pounds of toxic chemicals dollar revenue of the company, environmental lawsuits pending against the company (Konar \& Cohen, 2001), the level of pollution emissions released by the company (Stanwick \& Stanwick, 1998), environmental ratings (Russo \& Fouts, 1997), and the ratio of toxic waste recycled to total toxic waste generated (Al-Tuwaijri et al., 2004). In their review, Delmas and Blass (2010) summarised the measures of environmental performance into three main groups: (1) environmental impact (e.g. emissions, energy use), (2) regulatory compliance (e.g. non-compliance status, number of audits) and (3) organisational processes (e.g. environmental audits, accounting, reporting).

There were also some more complex measures. For example, Klassen and McLaughlin (1996) separately measured strong environmental performance with the announcement by an independent third party of winning an environmental award and poor environmental performance with an existing environmental crisis. 
In this paper, the emphasis is on environment performance investments, which will be measured with investment in new long-term assets. It is reasonable to assume that new assets will be more environmentally friendly and will thus result in improved environmental performance. Namely, newer asset contains newer and less polluting technology which results with better environmental performance and lower exposure to future environmental costs (Herbohn et al., 2014). The lower level of pollution of the newer asset has also been emphasised by Khanna et al. (2009), who also added that this asset could be more efficient as well. Newer equipment and cleaner technology are also more environmentally friendly (Du et al., 2014). Alrazi et al. (2016) are also claiming that newer assets are cleaner and have a lower impact on the environment, and due to that contribute to better environmental performance. On the other hand, the older asset can be less efficient in processing material and, therefore, can generate more pollution and waste (Cormier et al., 2004). Additionally, for a company with an older asset, it could be more difficult to meet environmental regulations or laws (Cormier et al., 2004). Therefore, the newer asset should result in lower emissions, reduced penalties due to issues related to pollution, a lower amount of energy consumption, waste reduction, lower costs of complying with the regulation, etc.

Related to this issue, Cochran and Wood (1984) found that companies with older assets had lower CSR ratings. Similar results were also reported by Strike et al. (2006), who argued that new technologies (new assets) allowed for a higher level of environmental responsibility. Elsayed (2006) has found that companies age is negatively associated with environmental performance, which was explained by the fact that younger companies have newer assets that do not breach environmental legislation and which are more energy efficient. Additionally, Rodrigue et al. (2013) have shown that companies with the newer asset are less likely to have regulatory problems.

Carrión-Flores and Innes (2010) have shown that there is a negative relationship between emissions and environmental patents in both directions. Therefore, companies that have higher levels of emission have fewer environmental patents, and in order to improve environmental performance (reduce emissions), investments into environmental patents (asset) should be made.

\section{Financial performance}

The measurement of financial performance is well developed and standardised, at least when compared to the measurement of environmental performance. Regardless of that, different ways of measuring financial performance can be found in literature, including accountingbased measures, market-based measures and a combination of the two (Galant \& Cadez, 2017). In this paper, financial performance is measured by using net profit or loss for the year 2018.

\section{Control variables}

As explained before, company size and leverage were included in this research as control variables. Company size was measured using the value of total assets for the year 2018. Due to a high deviation from total assets value, the natural logarithm of this value was calculated. Leverage was calculated as the ratio between total liabilities and total assets for the year 2018. The leverage variable indicates how the company's asset is financed, its own resources and/or liabilities. The highest the value is, the more liabilities are used to finance the company's asset. The leverage ratio is an indicator of business security. In line with the 
traditional view, a leverage value below 0.5 is acceptable considering the security of business, while the contemporary view suggests that values below 0.7 are acceptable.

\subsection{Sample description}

For the purposes of this research, the sample included 150 largest Croatian companies. The criterion for classifying companies by size was total revenues in the year 2018 (the last available data at the time of conducting the research). Financial institutions (including banks and insurance companies) were excluded from the sample since, for such companies, the data on investments in new long-term assets is not collected.

The data was collected from Poslovna.hr, a business portal specialised in providing key data about business (Poslovna.hr, 2020). All data referred to the business year 2018 (the last available year). The descriptive statistics of the used data are reported in table 1.

Table 1 | Descriptive statistics of the data used in analysis

\begin{tabular}{lllllll}
\hline & EPI & $\begin{array}{l}\text { \% of EPI in } \\
\text { total assets }\end{array}$ & $\begin{array}{l}\text { Total } \\
\text { asset }\end{array}$ & $\begin{array}{l}\text { In total } \\
\text { assets }\end{array}$ & $\begin{array}{l}\text { Net income } \\
\text { or loss }\end{array}$ & Leverage \\
\hline $\mathbf{N}$ & 150 & 150 & 150 & 150 & 150 & 150 \\
Mean & $157.37^{*}$ & 9 & $2,278^{*}$ & 20.71 & $67.60^{*}$ & 0.71 \\
Min & 0 & 0 & $108^{*}$ & 18.5 & $-948.35^{*}$ & 0.06 \\
Max & $3,036.40^{*}$ & 145 & $39,767^{*}$ & 24.41 & $1,334.29^{*}$ & 3.86 \\
Median & $22.15^{*}$ & 3 & $867^{*}$ & 20.58 & $34.68^{*}$ & 0.61 \\
Std. deviation & $391.43^{*}$ & 20.98 & $5,079.77^{*}$ & 1.13 & $201.45^{*}$ & 0.61 \\
Kurtosis & 24 & 24 & 31 & 0.93 & 17.01 & 13.63 \\
Skewness & 5 & 5 & 5 & 0.81 & 1.67 & 3.40 \\
\hline * million HRK (Croatian kuna) 1 EUR $\approx 7.5$ HRK (Croatian kuna) \\
EPI: environmental performance investments (investments in new long-term assets) \\
Source: authors' calculation
\end{tabular}

As evident from Table 1, there are significant deviations in the value of environmental performance investments (a high value of standard deviation), with the minimum value of 0 HRK (13 companies reported no such investment) and the max value of approximately 3 billion HRK. Although the sample comprised 150 largest companies, there are significant differences in company size (evident from total assets descriptive statistics). Therefore, the indicator share of environmental performance investments (investments in new long-term assets) in total assets were analysed. This value ranges from $0 \%$ (companies with $0.00 \mathrm{HRK}$ of investments) to $145 \%$, indicating that in this company, the value of environmental performance investments (investments in new long-term assets) was higher than the total value of the company's assets ${ }^{1}$. The mean value is $9 \%$, while the median value is $3 \%$. On average, the companies included in the sample operate with profits (the mean value of profit or loss is positive), and on average, $71 \%$ of their assets is financed with debt (short-term and long-term). The leverage ratio of 0.71 is at the margin of being acceptable considering the contemporary point of view.

In Table 2 the correlations between the variables used in the subsequent regression analysis are presented. In the regression analysis, the following variables were used: financial

\footnotetext{
${ }^{1}$ The data for Investments in new long-term asset represents the gross value, while the value of total assets represents the net value (the gross value decreased for amortization, value adjustments, etc.)
} 
performance (net profit or loss), environmental performance investments (investments in new long-term assets), size (In total assets) and leverage.

Table 2 | Correlation analysis

\begin{tabular}{|c|c|c|c|c|}
\hline & $\begin{array}{l}\text { Financial } \\
\text { performance }\end{array}$ & EPI & Ln size & LEV \\
\hline Financial performance & 1.00 & & & \\
\hline EPI & $0.385^{\star * \star}$ & 1.00 & & \\
\hline Ln size & $0.395^{\star \star *}$ & $0.433^{\star * *}$ & 1.00 & \\
\hline LEV & $-0.416^{\star * *}$ & -0.128 & 0.019 & 1.00 \\
\hline
\end{tabular}

Source: authors' calculation

As shown in Table 2, the variables environmental performance investments (EPI), leverage (LEV) and size are statistically significantly correlated with financial performance (net profit or loss $(p<0.01))$. The correlation between environmental performance investments $(E P I)$ and financial performance (net profit or loss), and between size and financial performance (net profit and loss) moderately positive ( $r=0.385$ and $r=0.395)$, while the correlation between leverage and financial performance (net profit or loss) is moderately negative $(r=-0.416)$. Additionally, the correlations between the variables financial performance (net income or loss) and size on the one hand, and environmental performance investments (EPI) on the other hand, are statistically significant $(p<0.01)$. Both of these correlations are moderately positive, $(r=0.433$ and $r=0.385)$. The correlation between leverage and investments is statistically non-significant $p>0.10)$.

\subsection{Method}

For the purposes of testing hypothesis $(\mathrm{H} 1)$, the defined model was tested using regression analysis. In the model, the dependent variable was financial performance (net profit or loss), and the predictors were environmental performance investments (investments in new longterm assets), size (In value of total assets) and leverage. Considering the three predictor variables, the sample of 150 companies is adequate (Horvat \& Mijoč, 2019).

\section{Results}

Before running the regression model, two diagnostic tests have been conducted: the test of homoscedasticity and multicollinearity. The results of testing homoscedasticity have shown that there are no problems with heteroscedasticity in the model. The scatterplot is presented in appendix 1. The multicollinearity was tested using VIF values. "The VIF is a tool to measure and quantify how much the variance is inflated" (Daoud, 2017). The VIF values are included in the table with regression results (Table 3). If the VIF value is greater than 10 , then there is a problem with multicollinearity between the independent variables. As it can be noted from Table 3, multicollinearity is not present in regression, and the model is suitable for further analysis $(\mathrm{VIF}<10)$. Additionally, the indicator of tolerance is not lower than 0.2 . Therefore the assumption of collinearity of independent variables is not violated (Horvat \& Mijoč, 2019).

The results of testing hypothesis $\mathrm{H} 1$ are presented in Table 3 below. In this model, financial performance (net profit or loss) is considered as a dependent variable, and environmental 
performance investments (investments in new long-term assets), size and leverage as independent variables (predictors).

Table 3 | Regression analysis results with financial performance as a dependent variable

\begin{tabular}{llllll}
\hline Variable & Coefficient & Std. error & Significance & \multicolumn{2}{c}{ Collinearity statistics } \\
\cline { 4 - 6 } & & & & Tolerance & VIF \\
\hline (Constant) & $-1,029^{*}$ & $268,02^{*}$ & 0.000 & 0.794 & 1.259 \\
EPI & 0.197 & 0.038 & 0.009 & 0.807 & 1.239 \\
Ln Size & 0.318 & $13,09^{*}$ & 0.000 & 0.977 & 1.024 \\
Leverage & -0.397 & $22.19^{*}$ & 0.000 & & \\
\hline$R^{2}=0.366$ & & & & \\
Adjusted $\mathrm{R}^{2}=0.353$ & & & & \\
Durbin-Watson $=1.939$ & & & & \\
$\mathrm{~F}_{(3,146)=28.132}$ & & & & \\
* million & & &
\end{tabular}

Source: authors' calculation

The regression analysis was used to test whether it was possible to predict the company's financial performance (net profit or loss) based on environmental performance investments (investments in new long-term assets), company size and leverage. Based on the $\mathrm{F}$ ratio, the whole regression model predicts the company's financial performance on a statistically significant level $(F(3,146)=28.132, p<0.01)$. The defined predicting variables (environmental performance investments, size and leverage) explain a $36.6 \%$ variance of financial performance (net profit or loss). The adjusted R 2 is 0.353 . The results of the Durbin-Watson test are 1.939 , which is close to 2 , so there are no problems with autocorrelation in this multiple regression (Horvat \& Mijoč, 2019). The predictive power of all three independent variables is statistically significant $(p<0.01)$. The predictive power of environmental performance investments (EPI) and size is positive, meaning that an increase in environmental performance investments leads to an increased profit (or a decreased loss) and that larger companies have higher values of business result (the size effect due to a larger value of assets). On the contrary, more indebted companies have a lower profit (or a higher loss). Although regression results have shown that the effect of environmental performance investments on financial performance is positive and significant, just a slight increase of financial performance as a consequence of environmental performance investments is reported. Namely, an increase of environmental performance investments for one mil HRK results in an increase of financial performance for just $197.000 \mathrm{HRK}$. Considering the results of the regression model, it can be concluded that hypothesis 1 (Environmental performance investments have a positive effect on financial performance in the short term) is accepted.

\section{Discussion and conclusion}

The interest in a company's environmental performance, together with its social performance, has recently become greater. Different parties wish to know how a company manages its environmental footprint. In order to respond to such demands, companies implement environmental management that aims to minimise the negative effect their business operations have on the environment (Klassen \& McLaughlin, 1996). Investments in environmental performance are an integral part of environmental management. Undoubtedly, investments in improved environmental performance contribute to the overall well-being of 
the natural environment and to preserving it as much as possible for future generations. Regardless of the benefits for the natural environment, and by taking into account Carroll's (1991) proposition that economic responsibility is the core responsibility of a company and the precondition for other responsibilities (legal, ethic and philanthropic), economists are interested in detecting how environmental performance investments affect companies' bottom line (i.e. financial performance).

The relationship between environmental performance investments and the company's financial performance was the focus of this paper. Therefore, the main aim of this paper was to analyse whether environmental investments could be used as a predictor of financial performance. The mentioned relationship was tested on a sample of 150 large-sized Croatian companies. For the purposes of this paper, environmental performance investments were measured with investments in new long-term assets since it had been expected that new assets would be more environmentally acceptable than older assets, while financial performance was measured using the companies' business results (profit or loss). Additionally, the effects of company size and leverage were also researched.

The results of this research show that environmental performance investments (investment in new long-term assets) can be used to predict companies' business results (profit or loss), i.e. more investments of this kind lead to improved financial performance (higher profit, lower loss).

The positive outcome of the relationship between environmental performance investments and financial performance is in line with the previous studies, which predominantly showed a positive relationship between environmental performance and financial performance (Horváthová, 2010). Improved environmental performance can contribute to financial performance through market gains and cost savings (Klassen \& McLaughlin, 1996). Market gains refer to increased market sale, and finally to increased revenues, while cost savings result in reduced expenses. Both situations lead to an increase in profit or decreased loss. Positive outcomes of this research confirm that manager's decision to accept social responsibility and to undertake pro-active strategies for controlling environmental impacts (AlTuwaijri et al., 2004) is legitimated from profit maximisation strategy since such behaviour contributes to companies' profits. Environmental performance investments could also be a useful tool for regain trust with investors and stakeholders and improve reputation (Salama, 2005). In such a way, the reputational advantage could be created and can lead to enhanced marketing and financial performance (Miles \& Covin, 2000). Therefore, managers may use environmental management practices as a part of their strategy to improve financial performance (Albertini, 2013).

However, the results between this study and other studies should be compared by keeping in mind the different measures for environmental and financial performance, but also the different samples. This leads to another issue concerning environmental accounting, which is the standardisation and harmonisation of environmental performance measures on the national but also international level. The existence of a standardised form of sustainability reports (includes environmental reporting component) would facilitate the comparison of these reports (Zrnić et al., 2020).

The main contribution of this paper is in detecting that environmental performance investments contribute to the company's financial performance. Therefore, environmental 
performance investments are of interest to the environment but also to the company since they improve its financial performance. Additionally, this is, to the best of our knowledge, one of the first studies that deal with the relationship between environmental performance investments and financial performance for Croatian companies.

The results of this study also have practical implications. Since a positive outcome was detected, managers could be encouraged to invest more resources in environmental performance due to the fact that they prove to be profitable for the company. By doing so, both the companies and the natural environment will reap benefit from these investments.

This research is not without limitations. The first limitation is related to the problem of the generalizability of the results since the study was conducted on a sample of only Croatian companies. Secondly, there are some limitations related to data. The environmental performance investments have been measured with investments into new long term asset, which include environmental, but also some other asset investments. Therefore, the entire research is based on the strong assumption about the connection between investments into new long term asset and environmental performance investments what is recognised as a research limitation. Future research should focus only on investments that are only environmental. Another limitation is related to the interpretation of regression results. Although regression analysis resulted in statistically significant results, the coefficient of the independent variable indicates the slight increase of financial performance as a consequence of environmental performance investments.

\section{Acknowledgement}

This paper is a result of scientific project "Accounting for the Future, Big Data and Economic Measurement" supported by the Faculty of Economics and Tourism "Dr. Mijo Mirković", Juraj Dobrila University of Pula. Any opinions, findings, and conclusions or recommendations expressed in this paper are those of the author(s) and do not necessarily reflect the views of the Faculty of Economics and Tourism "Dr. Mijo Mirković".

\section{References}

Albertini, E. (2013). Does environmental management improve financial performance? A meta-analytical review. Organization \& Environment, 26(4), 431-457.

Al-Tuwaijii, S. A., Christensen, T. E., \& Hughes Ii, K. E. (2004). The relations among environmental disclosure, environmental performance, and economic performance: a simultaneous equations approach. Accounting, organisations and society, 29(5-6), 447-471.

Berrone, P., \& Gomez-Mejia, L. R. (2009). Environmental performance and executive compensation: An integrated agency-institutional perspective. Academy of Management Journal, 52(1), 103-126.

Carrión-Flores, C. E., \& Innes, R. (2010). Environmental innovation and environmental performance. Journal of Environmental Economics and Management, 59(1), 27-42

Carroll, A. B. (1991). The pyramid of corporate social responsibility: Toward the moral management of organisational stakeholders. Business Horizons, 34(4), 39-48

Cochran, P. L., \& Wood, R. A. (1984). Corporate social responsibility and financial performance, Academy of management Journal, 27(1),42-56.

Cormier, D., Gordon, I. M., \& Magnan, M. (2004). Corporate environmental disclosure: contrasting management's perceptions with reality. Journal of Business Ethics, 49(2), 143-165. 
Dahlsrud, A. (2008). How corporate social responsibility is defined: an analysis of 37 definitions. Corporate social responsibility and environmental management, 15(1), 1-13.

Daoud, J. I. (2017). Multicollinearity and regression analysis. Journal of Physics: Conference Series, 949(1) 012009. IOP Publishing.

Delmas, M., \& Blass, V. D. (2010). Measuring corporate environmental performance: the trade-offs of sustainability ratings. Business Strategy and the Environment, 19(4), 245-260.

De Roeck, K., \& Delobbe, N. (2012), Do environmental CSR initiatives serve organisations' legitimacy in the oil industry? Exploring employees' reactions through organisational identification theory. Journal of Business Ethics, 110 (4), 397-412.

Drejeris, R., \& Oželienè, D. (2019). Modeling Environmental Actions of Corporate Sustainable Activity: Evidence from Lithuania. Central European Business Review, 8(5), 69.

Du, X., Jian, W., Zeng, Q., \& Du, Y. (2014). Corporate environmental responsibility in polluting industries: Does religion matter? Journal of Business Ethics, 124(3), 485-507.

Elkington, J. (1994). Towards the sustainable corporation: win-win-win business strategies for sustainable development. California Management Review, 36(2), 90-100.

Elsayed, K. (2006). Reexamining the expected effect of available resources and firm size on firm environmental orientation: An empirical study of UK firms, Journal of Business Ethics, 65(3), 297308.

Endrikat, J., Guenther, E., \& Hoppe, H. (2014). Making sense of conflicting empirical findings: A metaanalytic review of the relationship between corporate environmental and financial performance, European Management Journal, 32(5), 735-751.

European Communities. (2002). Communication from the commission concerning corporate social responsibility: a business contribution to sustainable development. Commission of the European Communities. Available at: https://ec.europa.eu/europeaid/sites/devco/files/communicationcorporate-social-responsibility-sustainable-development-com2002347-20020702_en.pdf (30.11.2017.)

Galant, A., \& Cadez, S. (2017). Corporate social responsibility and financial performance relationship: a review of measurement approaches. Economic Research-Ekonomska istraživanja, 30(1), 676693.

Herbohn, K., Walker, J., \& Loo, H. Y. M. (2014). Corporate social responsibility: The link between sustainability disclosure and sustainability performance. Abacus, 50(4), 422-459.

Horvat, J., \& Mijoč, J. (2019). Istraživački SPaSS [Research SPaSS], Naklada Ljevak, Zagreb

Horváthová, E. (2010). Does environmental performance affect financial performance? A meta-analysis. Ecological economics, 70(1), 52-59.

Kassinis, G., \& Vafeas, N. (2006). Stakeholder pressures and environmental performance. Academy of Management Journal, 49(1), 145-159.

Khanna, M., Deltas, G., \& Harrington, D. R. (2009). Adoption of pollution prevention techniques: the role of management systems and regulatory pressures, Environmental and Resource Economics, 44(1), 85-106.

Klassen, R. D., \& McLaughlin, C. P. (1996). The impact of environmental management on firm performance. Management Science, 42(8), 1199-1214.

Konar, S., \& Cohen, M. A. (2001). Does the market value environmental performance? Review of economics and statistics, 83(2), 281-289. 
Link, S., \& Naveh, E. (2006). Standardisation and discretion: does the environmental standard ISO 14001 lead to performance benefits? IEEE transactions on engineering management, 53(4), 508-519.

Melé, D. (2008). Corporate social responsibility theories, In Crane, A., McWilliams, A., Matten, D., Moon, J. \& Siegel, D. (Eds.), The Oxford handbook of corporate social responsibility, New York, USA: Oxford University Press, 47-82.

Miles, M. P., \& Covin, J. G. (2000). Environmental marketing: A source of reputational, competitive, and financial advantage. Journal of Business Ethics, 23(3), 299-311.

Nakao, Y., Amano, A., Matsumura, K., Genba, K., \& Nakano, M. (2007). Relationship between environmental performance and financial performance: an empirical analysis of Japanese corporations. Business Strategy and the Environment, 16(2), 106-118.

Nehrt, C. (1996). Timing and intensity effects of environmental investments. Strategic Management Journal, 17(7), 535-547.

Perić, J., \& Turalija, B. (2018). Corporate social responsibility as an important factor of business success in Croatian companies, Ekonomski vjesnik/Econviews, 31(1), 35-45.

Poslovna.hr. (2020). Available at: http://www.poslovna.hr/Login.aspx?ReturnUrl=\%2f (15.07.2020.)

Rodrigue, M., Magnan, M., \& Cho, C. H. (2013). Is environmental governance substantive or symbolic? An empirical investigation. Journal of Business Ethics, 114(1), 107-129.

Russo, M. V., \& Fouts, P. A. (1997). A resource-based perspective on corporate environmental performance and profitability. Academy of management Journal, 40(3), 534-559.

Salama, A. (2005). A note on the impact of environmental performance on financial performance. Structural change and economic dynamics, 16(3), 413-421.

Stanwick, P. A., \& Stanwick, S. D. (1998). The relationship between corporate social performance, and organisational size, financial performance, and environmental performance: An empirical examination, Journal of business ethics, 17(2),195-204.

Starčević, D. P., Mijoč, J., \& Zrnić, A. (2017). Is it worth going green in Croatia? Empirical Evidence from SMEs. Ekonomski vjesnik/Econviews, 30(1), 141-154

Strike, V. M., Gao, J., \& Bansal, P. (2006). Being good while being bad: Social responsibility and the international diversification of US firms. Journal of International Business Studies, 37(6), 850862.

Zrnić, A., Starčević, D. P., \& Crnković, B. (2020). Recent trends in sustainability reporting: Literature review and implications for future research. Ekonomski Vjesnik/Econviews, 33(1), 271-283

The research article passed the review process. | Received: October 30, 2020; Revised: February 23, 2021; Accepted: March 1, 2021; Pre-published online: April 30, 2021; Published in the regular issue: December 6, 2021. 


\section{Appendix}

\section{Appendix 1 | Scatterplot of analysed regression model}

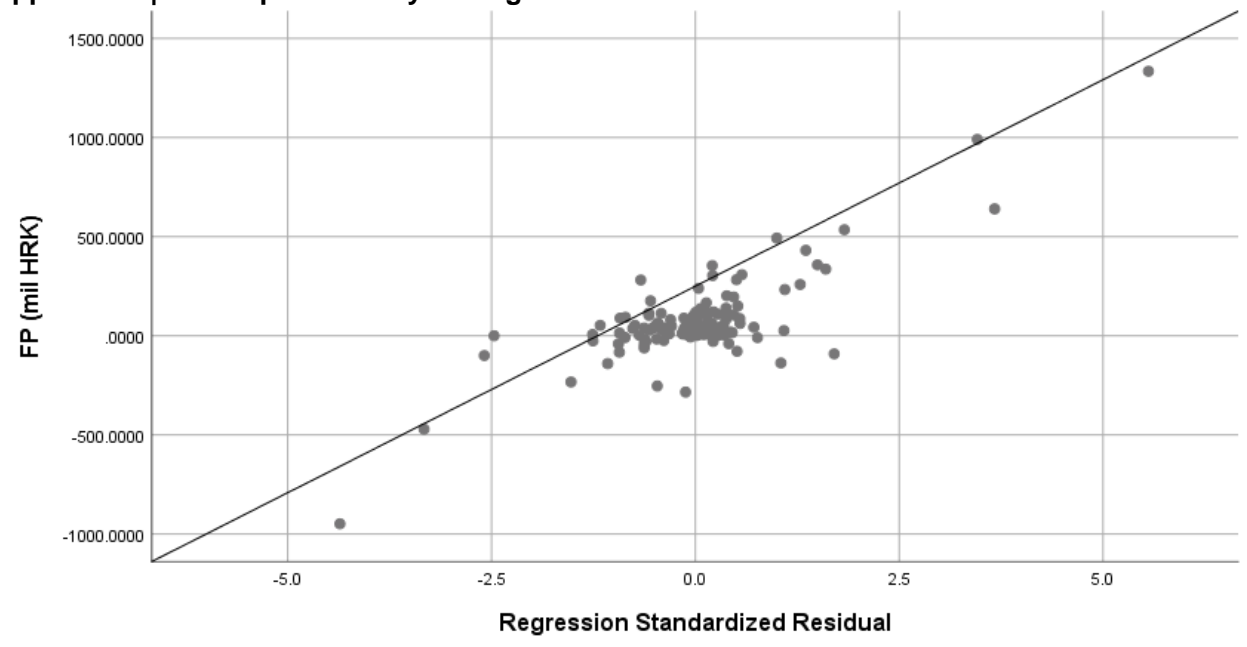

Source: authors 